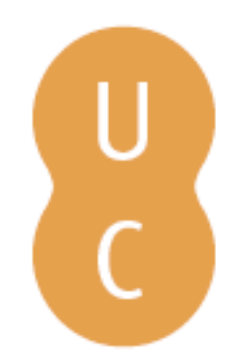

\title{
nommalina
}

\section{O risível, o lastimoso e o ridente em Metamorfoses de Apuleio: a dinâmica das relações sociais na Roma provincial}

\author{
Autor(es): $\quad$ Munhoz de Omena, Luciane \\ Publicado por: Imprensa da Universidade de Coimbra \\ URL \\ persistente: URI:http://hdl.handle.net/10316.2/34764 \\ DOI: $\quad$ DOI:http://dx.doi.org/10.14195/978-989-26-0626-2_14 \\ Accessed : $\quad$ 26-Apr-2023 09:12:33
}

A navegação consulta e descarregamento dos títulos inseridos nas Bibliotecas Digitais UC Digitalis, UC Pombalina e UC Impactum, pressupõem a aceitação plena e sem reservas dos Termos e Condições de Uso destas Bibliotecas Digitais, disponíveis em https://digitalis.uc.pt/pt-pt/termos.

Conforme exposto nos referidos Termos e Condições de Uso, o descarregamento de títulos de acesso restrito requer uma licença válida de autorização devendo o utilizador aceder ao(s) documento(s) a partir de um endereço de IP da instituição detentora da supramencionada licença.

Ao utilizador é apenas permitido o descarregamento para uso pessoal, pelo que o emprego do(s) título(s) descarregado(s) para outro fim, designadamente comercial, carece de autorização do respetivo autor ou editor da obra.

Na medida em que todas as obras da UC Digitalis se encontram protegidas pelo Código do Direito de Autor e Direitos Conexos e demais legislação aplicável, toda a cópia, parcial ou total, deste documento, nos casos em que é legalmente admitida, deverá conter ou fazer-se acompanhar por este aviso.

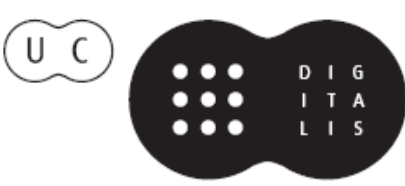




\title{
Saberes e poderes no Mundo Antigo
}

Estudos ibero-latino-americanos

\author{
Volume II - Dos poderes
}

Fábio Cerqueira, Ana Teresa Gonçalves, Edalaura Medeiros \& Delfim Leão (Orgs.)

IMPRENSA DA UNIVERSIDADE DE COIMBRA

UNIVERSIDADE FEDERAL DE PELOTAS

UNIVERSIDADE FEDERAL DE GOIÃS 


\title{
O RISÍVEL, O LASTIMOSO E O RIDENTE EM METAMORFOSES DE APULEIO: A DINÂMICA DAS RELAÇÕES SOCIAIS NA ROMA PROVINCIAL
}

\author{
Luciane Munhoz de Omena \\ Universidade Federal de Goiás - Brasil
}

\begin{abstract}
Como não ter Deus? Com deus existindo, tudo dá esperança; Sempre um milagre é possivel, o mundo se resolve. Mas, se não tem Deus, há-de a gente perdidos no vai-vem, e a vida é burra.
\end{abstract}

Guimarães Rosa

Grande Sertão: Veredas

Nesse artigo proponho discutir sobre as relações sociais nas províncias romanas a partir de duas comemorações descritas em Metamorfoses, de Lúcio Apuleio: uma dedicada à deusa Ísis e a outra ao deus do Riso. As festas exprimem sempre uma concepção de mundo, não apenas isto, mas também, como coloca Guarinello (2001), geram identidade entre os participantes, o compartilhamento do símbolo comemorado e se inscrevem também na memória coletiva. Nesse sentido a narrativa apuleiana permite que tracemos um perfil das estruturas sociais, culturais e políticas romanas do século II d.C.

\section{O RISÍVEL: UMA SÁTIRA DA DEGRADAÇÃO SOCIAL}

Balançando os braços com alternados esforços, tentava mover-me à maneira das aves. De penugem, entretanto, ou de penas, nenhum sinal; mas meus pêlos, sim, se espessaram em crina, minha mimosa pele se endurece como couro; a extremidade das minhas mãos, cessando o número dos dedos, todos eles se juntaram; da parte mais baixa da minha espinha, saiu uma longa cauda. O meu rosto, agora, torna-se uma face monstruosa, a boca se rasga, as narinas se abrem, e a beiçada fica pendente; minhas orelhas, com descompassado aumento, estão hirtas de hórridos pêlos (Apul. Met. 3.24).

Não há nada mais degradante e que seja motivo de riso do que ser transformado em um asno (ou como diriam alguns, num burro). Essa metamorfose escrita e dramatizada pelo protagonista Lúcio compõe a narrativa apuleiana, daí, o título Metamorfoses ou $O$ asno de Ouro. O protagonista Lúcio, aparentando pela linha materna com o filósofo Plutarco, viaja à Hípata e, nesta localidade, envolve-se com as artes mágicas, transformando-se em asno, passa por inúmeras dificuldades, para voltar a forma humana na festa dedicada à deusa 
$O$ risível, o lastimoso e o ridente em Metamorfoses de Apuleio

Ísis (Apul. Met. 11). A transformação em asno se deve a um erro cometido pela escrava Fótis. Esta tentando transformá-lo em ave, assim como o fez com sua senhora Panfília, passa o ungüento errado, mas o avisa que na manhã seguinte colheria rosas e, tão prontamente, seu amante voltaria a forma humana. Entretanto, na mesma noite, bandidos assaltam a casa de seu hospedeiro Milão e o levam juntamente com os objetos roubados, marcando assim, o início de várias aventuras, que servem para retratar os costumes da sociedade romana provincial (e.g. festas, adultérios, assassinatos, práticas mágicas, etc).

Nossa análise parte de dois elementos essenciais: o estilo de texto e a questão do riso como desencadeador do ultraje e da sublimação dentro das relações sociais nas províncias romanas do século II d.C.

1. Primeiramente, o enredo apresenta um conteúdo satírico-fantástico, que privilegia a paródia como veículo de relatos fantasiosos (MOTTA, 2006, p.165). O absurdo é inserido na narrativa a partir da metamorfose. Trata-se de uma narrativa de aventuras, de costumes (BAKHTIN, 1998) e de confissão (MOTTA, 2006), visto que o asno - Lúcio - narra suas próprias desventuras, traçando assim "suas aventuras, confessando no lugar do heroísmo, a fragilidade e os sofrimentos contidos num ritual de peregrinações" (MOTTA, 2006, p.161-2). Intensifica-se a consciência de seu sofrimento pelo castigo externo das agressões corporais. Tal consciência, como propõe Motta, reflete uma esfera de perdição da qual poderá retornar, "porque o circuito da representação realista faz o destino do homem girar pelas voltas desse labirinto simbólico, cujo ponto mais alto de afloração é o das relações humanas" (MOTTA, 2006, p.218).

Essa representação realista possui um traço indispensável e ambivalente: trata-se de um estado de transformação, mas ainda incompleto por aparecerem o estágio da morte e do nascimento. A própria metamorfose em asno comporta elementos do "baixo material e corporal", imprimindo valores de degradação e regeneração (BAKHTIN, 1999). O protagonista, após todos os infortúnios, retorna a forma humana pela intervenção da deusa Ísis, fazendo-o aprender pelo sofrimento. Esse caráter regenerador é positivo em termos sociais, pois, Lúcio entra para o colégio dos pastóforos da deusa e é elevado a ordem dos decuriões.

A salvação de Lúcio é evidente, no entanto, uma exceção, porque, a representação realista evidencia sempre situações de degradação humana: os personagens são sempre dramatizados pela angústia, constituídos pela figura "fragilizada do homem anti-herói, colocando em cena o drama de suas angústias particulares" (MOTTA, 2006, p.245). Lúcio é um anti-herói, oscila entre os movimentos de queda e redenção. Entretanto, outras personagens, assim como as femininas são representadas pela inconsequência, pôr utilizarem a magia sem a permissão dos deuses, aliás, de forma independente, visando aos interesses próprios e como parte de uma trama realista, sobrevivem causando desordens e 
não recebem sanções sociais. A personagem Panfília, esposa de Milão, é um exemplo de imprudência: a maga mantem sobre a cidade certa proeminência conquistada pelo medo, pois, seu conhecimento mágico poderia ser exercido contra os citadinos ou contra indivíduos, os quais atuassem contrariamente aos objetivos da feiticeira. No livro II, Apuleio condena-a pela boca de Birrena: "Guarda-te, guarda-te energicamente dos perigosos artifícios e da sedução criminosa dessa Panfília, mulher do Milão que tu dizes ser teu hospedeiro. Ela passa por mágica de primeira ordem, e entedida em todos os gêneros de encantamentos sepulcrais" (Apul. Met. 2.5).

A crítica apuleiana refere-se à postura de Panfília, principalmente, por utilizar a magia por motivos tão torpes quanto à infidelidade, deixar os afazeres de dona-de-casa confiando-lhes a escrava Fótis e até dando-Ihe autonomia, e, por fim, a maior reprovação encontra-se na postura passiva do marido (Apul. Met. 2.12). Este tipo de condenação faz parte da representação realista, e proporciona aos homens à visualização do

drama de si mesmo e da simbolização do inferno de sua vida, representado na alegoria da metamorfose de sua queda. Tendo como fundo do palco o espectro da morte de sobreaviso, o seu drama não lhe reserva a possibilidade de vitória. É a vitória da ironia que comandará a derrota de sua nova trajetória (MOTTA, 2006, p.170).

Ou seja, a ironia indica a vitória do "verme vencedor" (ALLAN POE, 1981, p.955 Apud MOTTA, 2006, p.171), garantindo, assim, o triunfo de Panfília, uma mulher que utiliza seu tempo praticando a arte mágica, a qual lhe serve como uma forma de exercitar e ampliar sua autonomia. Apuleio, contudo, mais do que recriminar sua atuação faz críticas ao descaso masculino. A narrativa é um tipo de precaução quanto aos rumos do que o autor considera por declínio social, qual seja: a mudança de comportamento das mulheres. Panfília representa mulheres, as quais surgem em razão de os homens não as controlarem.

2. O segundo elemento a ser vislumbrado é o riso, pois, é uma das características da narrativa apuleiana, pôr estruturar-se, juntamente, com o gênero de representação realista, em que todas as situações sociais apresentadas na narrativa são risíveis. Ora, a passividade de Milão, frente à autonomia de Panfília, torna-o ridículo. O comando de Fótis, escrava de Panfília, na relação sexual com Lúcio, colocando-o em posição de passividade, demonstra o domínio da personagem feminina sobrepondo-se a potestas masculina (Apul. Met. 2.9-10). Não é sem motivo, que este mesmo personagem degrada-se com a transformação em asno, logo, torna risível sua condição anterior, que deixa ser dominado por uma mulher e, ainda mais, uma mulher de condição escrava, tornando, dessa forma, sua degradação mais cômica, mais condenável. Ou em outras situações representadas na narrativa, as quais extrapolam o núcleo 
O risível, o lastimoso e o ridente em Metamorfoses de Apuleio

doméstico, incluindo outras esferas de poder como o banditismo, a fuga de escravos ou a própria inoperância das estruturas de domínio romano, criticado por Apuleio, através de seu conhecido Píteas, que se encarregava da anona e exercia também a função de edil. Este, após cumprimentar Lúcio, pois, há muito não o via, pergunta o valor pago por seus peixes, e ao descobrir que o repasto custou vinte denários, descontrola-se, obrigando Lúcio a apontar o vendedor. Ao aproximar-se deste, Píteas, pensa puni-lo, apenas por ter jogado os peixes no chão, pisando-os e aos gritos, repreende o velhinho. O modo como agiu o edil, tornou-se ridículo aos olhos do protagonista, pois, o vendedor foi somente afrontado publicamente, não devolveu a quantia a Lúcio e este sim, perdeu com a performance de Píteas: voltou a casa de seu hospedeiro Milão, com as mãos abanando, sem os víveres de seu jantar (Apul. Met. 2.24-25).

Essas são características zombeteiras por apresentarem realidades grotescas como a ineficiência de Píteas, visto que o leitor-ouvinte é conduzido, assim como o protagonista, a uma resolução eficiente na qual, espera-se, pelo menos, ter o dinheiro ou a diminuição do valor da mercadoria, mas, pelo contrário, perde-se tempo e capital. Evidencia-se, dessa forma, o predomínio de um mundo instável em que tudo é possível, em que todos os valores desaparecem.

Nessas aventuras grotescas, não há nem bem nem mal, belo e feio, mas simplesmente peripécias que determinam o riso embaraçado e vagamente perturbador. É um romance diabólico, a começar por seu herói, já que se trata das tribulações de um asno, animal que encarna os maus instintos, as forças maléficas, a sensualidade desenfreada (MINOIS, 2003, p.95).

Esta diabolização da narrativa apuleiana caracteriza a suposta adaptação das Metamorfoses, do satirista grego Luciano de Samósata. Conforme Minois (2003, p.67), este "zomba dos zombadores, ri dos que riem e duvida do ceticismo, atinge a negação absoluta, o nada", quer dizer, ao considerar a vida uma comédia grotesca e absurda, tudo é passível de ridículo: filósofos, deuses, charlatões e até ele mesmo.

Deve-se demarcar, sobretudo, a existência de dois risos em Apuleio:

O primeiro riso é o profano, o do dia-a-dia, o do cotidiano, retratado nas cenas de autonomia das personagens femininas, as quais atuam sempre por interesses próprios, como vimos anteriormente, ou a descrição apuleiana acerca da avareza de Milão, "um homem que possui haveres em abundância, mas desacreditado por sua extrema avareza e sórdida baixeza" (Apul. Met. 1.21). Uma derrisão que se aproxima das sátiras de Samósata por prevalecer um riso agressivo, desvelando a criação de uma ilusão, de um logro, pois, a sociedade constitui-se por seres degradantes e são estes, os quais darão ritmo a vida. É risível a avareza de Milão e ainda mais deplorável: é roubado em sua própria domus, evidenciando-se a inutilidade de sua mesquinhez, para mostrar o quanto 
a existência humana é alardeada pela ironia e pela instabilidade: o desfrute de sua riqueza será aproveitado por um grupo de bandidos (Apul. Met. 3.28).

O segundo riso é o sagrado, que por estar vinculado às divindades, permite a busca através delas da ordenação social e do equilíbrio. Diferentemente de Samósata nos quais os imortais em - $A$ assembléia dos deuses e Diálogos dos deuses - são ridículos por se queixarem de seus trabalhos e, com isso, passam o tempo brigando. Em Apuleio, a salvação dos homens e a conquista de benesses nos planos político e social dar-se-ão pelas intervenções divinas, diferentemente da proposta do satirista grego. O que caracteriza um dos eixos centrais da narrativa apuleiana: o descrédito dos homens pelos deuses. Tomo como ponto de partida, duas narrativas inseridas nas Metamorfoses:

1. A jovem Psiquê, filha de um rei, dotada de rara beleza não consegue casar-se pelo fato de os homens terem receio de sua formosura. Tal perfeição ganha fama, a tal ponto que se estende para além das fronteiras do reino, gerando, com isso, a crença de que se trata de uma deusa e não de uma mortal. A população descuida-se da manutenção do culto da deusa Vênus e, então, a divindade possuída de grande cólera manda uma série de desgraças ao reino de Psiquê. Seu pai preocupado com os infortúnios e com o destino de sua filha, sem uma relação matrimonial, encaminha-se até o oráculo e recebe a aterradora notícia:

Sobre o rochedo escarpado, rei, expõe a tua filha, para o himeneu de morte, pomposamente enfeitada. Então não esperes para teu genro, criaturas originadas de mortal estirpe, mas um monstro cruel e viperino, que voa pelos ares e, feroz e mau, não poupa ninguém (Apul. Met. 4.33).

Esta penalização sofrida pela jovem princesa se dá por um elemento importantíssimo caracterizado pela incredulidade dos homens na deusa Vênus. Isso promove dois problemas relacionáveis: ao deixar de ser cultuada, Vênus é afastada da memória coletiva dos homens e, por consequência, o reino é assolado por desequilíbrios sociais, pois, há uma preeminência do sagrado, embora a crítica apuleiana se concentre na incredulidade de seus contemporâneos.

2. A segunda narrativa refere-se ao desrespeito do protagonista aos cultos religiosos, porque, assim como Méroe (Apul. Met. 1) e Panfília (Apul. Met. 2), Lúcio utiliza a magia como forma de manipulação de poderes superiores sem o auxílio das divindades. $O$ culto religioso se separa da magia por responder pela crença em seres sobrenaturais, os quais regem conscientemente o mundo de acordo com sua persuasão, enquanto, a magia é o produto das operações de leis imutáveis, por conseguinte, o conhecimento e a intervenção das feiticeiras nestas leis naturais é quem produzirá a magia, sem a presença dos deuses. 
A reprovação de Apuleio as práticas mágicas perpassa a não ritualização dos cultos aos deuses, assim como apresenta-se no conto de Psiquê e Cupido, na qual Vênus deixa de ser cultuada e, consequentemente, ritualizada. Há um entrelaçamento entre o culto religioso e a magia, posto que a transformação de Lúcio-Asno em humano deve-se a uma intermediação mágica, que se estabelece pela interferência direta da deusa Ísis em sua procissão, através da ingestão de rosas disponibilizadas por seu sacerdote (Apul. Met. 11). No mesmo livro, o autor posiciona a deusa acima dos homens e até mesmo de outras divindades, para enfatizar seu poder e demonstrar a seus contemporâneos a superioridade de Ísis: se comparada a atuação das feiticeiras, as quais agem de forma individualizada, tornam-se insignificantes, pois a deusa comanda o todo.

Para demonstrar a grandeza e a imponência de Ísis, após a aparição da deusa na praia, Lúcio-Asno sem questionar a ordem divina, aproxima-se do sacerdote e ingeri as rosas, mas antes de comê-las, eis que observa: "de todos os lados, como num dia de festa, e mais propriamente de triunfo, grupos animados enchiam as ruas" (Apul. Met. 11.7). A primeira vista, temos a alegria do personagem em despojar-se da figura de asno, mas também pode-se observar, a partir de suas palavras, uma ação coletiva, levando-se em consideração o envolvimento de toda a cidade de Concréias, colônia de Corinto (Apul. Met. 10.35), experimentando sentimentos e emoções, os quais são seguidos dos "prelúdios da grande pompa gradualmente se [avançando], ornada belíssimamente segundo o votivo de zelo de cada um" (Apul. Met. 11.8).

Daí considerar a procissão isíaca uma comemoração festiva, pois, interpreto-a como um fenômeno social por implicar uma ação coletiva, na qual se enfatizam sentimentos e emoções experimentadas pelos participantes. Não é sem motivo, que houve um cuidado pessoal, de cada um dos representantes de Concréias, para que a festa agradasse a divindade e, assim a população pudesse alcançar seus favores, do mesmo modo que Lúcio.

Sendo assim, apresentam-se na procissão isíaca mulheres esplêndidas vestidas de branco, as quais exprimem alegrias com vários gestos: "floridas com coroas da Primavera, tiravam as pétalas de seus seios e as jogavam no chão pelo caminho por onde marchava o cortejo sagrado" (Apul. Met. 11.9). Além de mulheres participam homens com fachos, velas de cera, para evidenciar as benções daquela de quem se originam os astros do céu. Seguindo a procissão, incluem-se ainda as sinfonias de flautas, o coro composto por jovens nobres cantando um poema dedicado a deusa, e, então, "aflui grande multidão de iniciados nos sagrados mistérios, homens e mulheres de todas as hierarquias e toda a idade, resplandecentes com a brancura imaculada de suas túnicas de linho" (Apul. Met. 11.10). Os sacerdotes dos sagrados ritos são ilustres cidadãos com "vestimentas de linho branco que, apertada no peito e pendendo até os pés, 
conduziam os insignes despojos dos potentíssimos deuses" (Apul. Met. 11.10). O primeiro deles carrega um barquinho de ouro, o segundo leva em suas mãos dois altares, o terceiro ergue uma palma feita de folha de ouro, o quarto

mostrava o emblema da justiça - a mão esquerda com a palma aberta: naturalmente lenta, despojada de agilidade e segurança, a esquerda parecia, mais que a direita, convir a justiça. Levava ele, na outra mão, um vasinho de ouro arredondado em forma de mama, com a qual fazia libações de leite. Um quinto tinha uma caixa de ouro carregada de raminhos de ouro, e o sexto, uma ânfora (Apul. Met. 11.10).

Os indivíduos e suas posições na procissão seguem o ordenamento social, ou seja, as funções especiais são delegadas aos cidadãos ilustres, como os sacerdotes dos ritos sagrados, o coro, os quais cantam cantigas à deusa ou o grão sacerdote, que ao finalizar o cortejo, entoa as últimas preces, para depositar os presentes e os objetos votivos no barco (Apul. Met. 11.16), enquanto, a turba de iniciados nos cultos mistéricos, homens e mulheres de todas as idades e posições sociais, vestidos de linho seguem o cortejo (Apul. Met. 11.10). Ao final da procissão, o grão sacerdote dirige-se ao templo, juntamente, com os demais sacerdotes e os iniciados, para convocar o grupo dos pastóforos da deusa e pronunciar os votos de prosperidade aos agentes sociais, representados pelo domínio romano através do príncipe soberano, do senado, da ordem eqüestre e do povo romano.

Esse pronunciamento demarca, primeiramente, as boas relações do culto isíaco com a auctoritas romana, com o poder oficial. Devemos recordar que alguns cultos mistéricos como o de Ísis foram reprimidos por serem cerimônias secretas e poderem "ocultar perigosas reivindicações da massa popular, que aderia a elas em grande número" (SCARPI, 2004, p.166). Augusto proibi a celebração dos rituais de Ísis no interior do pomoerium, no governo de Tibério é ordenado a demolição do santuário e sua imagem é jogada no Tibre, enquanto, no século de Apuleio, as autoridades permitem a realização do culto e todo o seu cerimonial. 0 último livro das Metamorfoses é um reflexo dessa oficialização. Como vimos, Lúcio Apuleio descreve em detalhes a realização da procissão e dos ritos de iniciação à deusa através da transformação do Asno-Lúcio em homem (Apul. Met. 11.6) e, talvez a associação mais relevante seja à do culto com os poderes romanos e seus domínios, pois, segundo as palavras do protagonista, a proteção incluiria também os navegadores e os "navios que, no mundo inteiro, estão sob a lei do nosso império" (Apul. Met. 11.17).

Ora, a utilização do pronome "nosso" indica uma assimilação de uma identidade romana por parte de Apuleio, a partir disto, deve ser mencionado que o autor nasceu na cidade de Madaura, província africana localizada entre a Numídia e a Getúlia. Como afirma o próprio autor em Apologia (Apul. Apol. 24.1): "quanto à minha pátria ela está situada entre os limites da Numídia e da Getúlia. 
O risível, o lastimoso e o ridente em Metamorfoses de Apuleio

Eu declarei de fato que era semi-númida e semi-getulo", portanto, temos um africano que se identifica com sua região de origem, mas se inclui como pertencente ao poderio romano.

No entanto, essa integração não elimina a manutenção das "identidades étnicas", pois, mantiveram-se por todo o império, por isso, a autodenominação de Apuleio como sendo semi-númida e semi-getulo ou mesmo o imperador Septímio Severo ser africano. São, justamente, as identidades étnicas, as quais se tornam presentes em discursos como no diálogo entre Birrena e Lúcio nas Metamorfoses, na qual a anfitriã afirma que a cidade de Hípata, sua pátria, é esplendorosa pelos templos, banhos e outros edifícios públicos, se comparada às diversões na cidade de Roma - um forasteiro ativo em nada perderia. Este discurso suscita, pelo menos, uma questão: Hípata é tão equipada de divertimentos quanto a cidade de Roma (Apul. Met. 2.19). Esta, considerada ainda neste período grande centro, é um contra-exemplo para dignificar as belezas da cidade de Birrena e evidenciar a relevância dela como parte do imperium. A personagem procura construir certa identidade enquanto cidadã de Hípata, permitindo, dessa forma, manter-se ligada aos grupos aos quais se identifica culturalmente, se reconhecendo como iguais e se distinguindo, ao mesmo tempo, de outros setores sociais e de outras regiões do império romano. Como nos lembram Gonçalves e Rocha,

uma forma de se vestir, de se comportar, uma linguagem específica, pode simbolizar adesão a um determinado processo de identificação, gerando fidelidades e lealdades a um determinado grupo, mas também o afastamento de outros setores sociais, com os quais o processo de identificação não se define (2006, p.12-3).

Esse processo de assimilação das elites a potestas romana e, ao mesmo tempo, o destaque às identidades étnicas, enquanto, processo identitário, levame a afirmar, assim como o fez Guarinello, de que o Império Romano, pelo menos até o IV século, constituiu-se pela multiplicidade cultural e, mais ainda, o governo imperial sempre teve como pretensão "gerenciar e controlar essa diversidade". As formas de gerenciamento, dependeu de época para época, mas, de modo geral, e aqui mencionarei apenas uma, a qual interliga-se a presença do culto de Ísis em Concréias, que é o sincretismo religioso, definido por Guarinello, como sendo uma releitura e uma inserção das "crenças locais num panteão pluriétnico, permanentemente aberto à incorporação de novas divindades (GUARINELLO, 2009, p.152-53).

Temos a presença de um culto egípcio, com todo o seu aparato, praticado por elites locais e demais grupos sociais sob os auspícios do poder romano, sendo, portanto, um instrumento de legitimação da posição das autoridades romanas e da supremacia das elites nas cidades do Império. Embora a procissão de Ísis esteja hierarquizada socialmente, a crença em seu culto e a necessidade de os homens 
seguirem suas ritualidades, para assim, se aproximarem da divindade, os motiva à realização da festa, por isso, a procissão ísiaca é um polo de agregação entre os devotos, assim como também é um elemento identitário e, por conseguinte, diferenciador do domínio romano.

Ao lado dessa "pomposa procissão propriamente dita da deusa da Salvação" (Apul. Met. 11.9), apresenta-se uma procissão de mascarados, composta pelo riso, pelo escárnio e com encenações realizadas pelo povo, as quais retratam os diversos grupos sociais e seus símbolos a exemplo do magistrado com o feixe e a púrpura, o gladiador reconhecidamente com perneiras, escudo, capacete e espada ou a presença de ornamentos indicando o costume de as matronas usarem adornos nos cabelos, o que torna evidente o pertencimento dessas mulheres à aristocracia (Apul. Met. 11.8).

O que é de extrema relevância, pois, alguns autores interpretam as festas como sendo momentos em que se "instaura e constitui um outro mundo, uma outra forma de experimentar a vida social, marcada pelo lúdico, pela exaltação dos sentidos e emoções - com um forte acento hedonista e agonístico - e, mesmo, em grande medida, pelo não-social" (PEREZ, 2002, p.18). Nessa procissão, Apuleio mostra-nos, contrariamente a Perez, uma forte presença dos elementos sociais como filósofos, magistrados, mulheres aristocratas, caçadores, gladiadores, soldados, entre outros, os quais formam a sociedade romana provincial. Daí o ato festivo, sendo produto da realidade social, compor-se de conflitos, tensões, censuras e as estruturas de poder (GUARINELLO, 2001, p.272), as quais são presenciadas pelas brincadeiras jocosas deste cortejo.

O lúdico e o exagero não eliminam a caracterização social, mas, em nosso caso, acrescenta um importante fator: o elemento popular do festejo apuleiano que se constitui por representações caricatas desses agentes sociais. Este riso explícito, dado pelas bufonarias, em que setores aristocráticos são representados de forma ridícula assim como "uma ursa domesticada, que era levada em uma liteira com o ornato de uma matrona" (Apul. Met. 11.8), indica sim uma inversão da ordem, mas essa carnavalização não exclui a representação e a ordem social, muito pelo contrário, o riso assegura as estruturas de poder, o renascimento e, ao mesmo tempo, garante a participação da multitudo no espetáculo a partir de suas próprias expressões acerca de si, que também refletem a representação destes setores acerca do universo dos nobres.

\section{ENTRE LÁGRIMAS E RISOS:}

Nessa perspectiva, pode-se afirmar um outro elemento, proposto pelo professor Trabulsi, em seu livro intitulado - Dionisismo, poder e sociedade na Grécia até o fim da época clássica - de que o culto isíaco, assim como o dionísiaco, foram os únicos a receberem um ritual por parte de todos os egípcios 
O risível, o lastimoso e o ridente em Metamorfoses de Apuleio

(2004, p.130). Baseando-se nos manuscritos de Heródoto, estabelece "uma correspondência, uma identificação, entre as divindades gregas e as divindades egípcias. Neste quadro, Dioniso é o equivalente de Osíris. Seria melhor dizer que ele é Osíris" (TRABULSI, 2004, p.133). Como propõe Fortuna (2005, p.78), é possível estabelecer a partir de Dioniso, sua relação com Osíris, pois, este

era o juiz e senhor dos mortos, por conseguinte, regenerador da vida. Só, que, assim como a morte não afetou a imortalidade do filho de Zeus nascido duas vezes, Osíris também é concebido como o "morto imortal", assim como Plutão é o "imortal deus da morte". Representam mortes de catábase e de anábase (quando uma divindade nasce, morre, nasce, morre, torna a nascer e torna a morrer), sucessivamente ${ }^{1}$.

No Egito Antigo, Osíris é celebrado em duas instâncias que se alternam: pela tristeza (provocado pelo choro) e pela alegria (provocado pelo sorriso) o que se aproxima de Dioniso, pois, nas cerimônias dionisíacas existiam representações de tristeza e alegria, especialmente, nas apresentações cênicas. Esse riso sagrado pode ser vislumbrando em outra passagem das Metamorfoses, precisamente no festejo do deus do Riso, no qual o personagem Lúcio pensa que será punido pela morte de três jovens e entra em desespero chorando, enquanto, a multidão às gargalhadas se descontrola. Esta representação cênica é parte da ritualidade das cerimônias do deus do Riso e, ao mesmo tempo, pode ser relacionada às festividades de Dioniso e Osíris. Por isso, seguindo a assertiva de Trabulsi (2004), mesmo se tratando de autores como Heródoto e Apuleio, os quais viveram em épocas distintas, estabeleço a seguinte hipótese: dada a influência do culto dionisíaco no Egito e, ao mesmo tempo, a proximidade do autor madaurense aos cultos mistéricos isíacos, suponho algumas correspondências entre os deuses Dioniso e o Riso no que se referem ao êxtase desvairado, ao riso, às encenações, às metamorfoses entre outros aspectos.

A festa do Riso é introduzida no enredo, no momento em que Lúcio, após um convite de Birrena, vai a um banquete em sua residência. Saí tarde da noite, quando é abordado por três bandidos e num ato de defesa mata-os, protegendo a si próprio e a casa de seu hospedeiro, Milão. No dia seguinte foi preso e julgado pelas mortes. Começa então a brincadeira sagrada. Lúcio, sem saber, e, com isso passando por todos os temores de um julgamento, descobre ao final ser apenas parte de um ritual: uma festa dedicada ao deus do Riso. O protagonista após o desfecho da festa é agraciado com homenagens, sendo oferecido a ele, honras extraordinárias: é nomeado patrono da cidade de Hípata e elevam uma estátua de bronze (Apul. Met. 3.11).

Lúcio é escolhido por dois motivos. O primeiro e o mais óbvio: por ser um forasteiro, assim não reconheceria o gracejo da festa; e, em segundo, por pertencer ao grupo de notáveis, engrandeceria o momento festivo - com sua 
dignidade - e o reconhecimento do deus ao próprio Lúcio e à cidade, conquistando os seus favores e a sua amizade. O que fica evidente é que, além da proteção do deus, Lúcio receberia vantagens tão sólidas quanto a honra: a partir dela, o protagonista poderia aumentar seu círculo de relações e ampliar igualmente seus benefícios.

Mesmo obtendo vantagens, Lúcio deveria ser ridicularizado no festejo e, por isso, sente-se estupefato ao descobrir que tudo não passara de uma brincadeira: matara apenas três odres. De acordo com a narrativa, "nenhuma palavra haverá capaz de exprimir o imprevisto de tal espetáculo. Os cadáveres de nossos degolados eram três odres estufados com rasgões" (Apul. Met. 3.9).

Essa comicidade dramatizada por Lúcio apresenta-se no teatro, assim como nas festas dionisíacas. Estas apareceram inicialmente nos concursos de tragédia, em 501 a.C. e as comédias, quatro anos mais tarde. As peças eram animadas por "um coro de sátiros, personagens fantasmagóricos, companheiros de Dionísio e dirigidos por um bêbado lúbrico, Silênio" (MINOIS, 2003, p.36). Dioniso é o patrono do teatro e as representações estão inseridas em suas festas (TRABULSI, 2004, p.144), por isso, encontram-se em suas festividades a mistura entre a ilusão e o real.

Assim como no festejo do deus do Riso: seu cenário principal é o teatro "onde se apresenta a sociedade oficial e, inversamente em que se manifesta o protesto popular" (BALANDIER, 1982, p.12) - e é, neste local, que se encena o julgamento do protagonista Lúcio, no qual se evidencia uma alegria especial e "licenciosa" do pensamento e da imaginação. Em meio ao espetáculo, Lúcio é apanhado na casa de seu hospedeiro, por ordem dos magistrados e arrastado até o Fórum. Sem compreender o que esta acontecendo, não impõe nenhuma resistência, apenas avança com "os olhos tristemente baixados para o chão" (Livro III, II). Quando percebe, vê uma multidão que o seguia, formando um cortejo e escuta, em uníssono, o povo exigir que o julgamento acontecesse no teatro. De acordo com suas palavras:

Amontoaram-se nos corredores de acesso e até nos vigamentos do teto. Muitos se atracaram às colunas, abraçando-as. Outros se suspenderam às estátuas. Encheram as fendas das janelas e as aberturas todas - todos ávidos de ver, tanto que se esqueceram do perigo a que se expunham. Então, os funcionários da cidade me avançaram, como uma vítima, atravessando a cena, e me colocaram no meio da orquestra (Apul. Met. 3.2).

Monta-se uma audiência no teatro e Lúcio é acusado por um homem de certa idade - o que proporciona veracidade à narrativa - de ter matado cruelmente três jovens. O espetáculo é ainda mais dramatizado no momento em que entraram duas mulheres desconhecidas, provavelmente do povo, pedindo 


\title{
O risível, o lastimoso e o ridente em Metamorfoses de Apuleio
}

que o acusado sofresse as devidas penalidades. Segundo a aclamação delas, a misericórdia pública deveria socorrer "ao menos a criancinha, deixada sem proteção nos seus verdes anos e oferecei o sangue desse bandido, como expiação, às vossas leis e à ordem pública" (Apul. Met. 3.8). Diante da aclamação das duas mulheres, o magistrado mais velho - duvidoso da acusação - e não encontrando o escravo que o acompanha, ordena a tortura de Lúcio. Este, desesperado, sem a presença de seu escravo e tendo somente suas palavras contra as acusações, vê os instrumentos de tortura: o fogo, a roda e os látegos (Apul. Met. 3.9).

Sem muito o que fazer, chora e observa um fenômeno perturbador: a multidão às gargalhadas (Apul. Met. 3.2). O povo se descontrola no ápice da cena: as gargalhadas e os gestos aumentam vertiginosamente no momento em que se revela a morte apenas de três odres. Segundo Lúcio:

Então, o riso, que alguns tinham tido a malícia de reprimir por um momento, explodiu livremente e se propagou através da multidão. Uns, no excesso da alegria, cacarejavam, outros seguravam a barriga com as duas mãos para que fizesse menos mal e foi com uma transbordante satisfação que todos deixaram o teatro, voltando-se para olhar-me (Apul. Met. 3.10).

Assim como na narrativa apuleiana, o riso dionisíaco "é democrático todos podem rir - é popular e universal (FORTUNA, 2005, p.86). Estes rituais são acompanhados por desordens verbais o que gera o riso e, por consequência, a proteção e o contato com o mundo divino. Cria-se, na narrativa apuleiana, uma ilusão de punição, com a inclusão de possíveis torturas e uma multidão ululante exigindo a condenação de Lúcio. Como acentua Fortuna (2005, p.103), Dioniso

\begin{abstract}
é um deus frenético, incitador de sons caóticos, os sons enlouquecedores das multidões eufóricas, que mais enlouquecidas ficam com sua dança e sua música se não o honram como devem (...). Dioniso é o deus que desencadeia a embriaguez, o delírio e a alucinação" e, dessa forma, o riso e o choro eram carnavalizados, "liberando, ao mesmo tempo, lágrimas entre gargalhadas e gargalhadas entre lágrimas.
\end{abstract}

Essa carnavalização associada ao grotesco nas dionisíacas apresentam-se por animais como bodes, corujas, asnos, os quais servem para ridicularizar "todos os estados da vida e todas as posições do poder. Imagens alegóricas mistas formadas pelo humano e pelo animal reivindicam, amedrontam, podendo, consentaneamente, divertir" (FORTUNA, 2005, p.95). Esta ridicularização apresenta-se na narrativa apuleiana a partir de duas fases: Lúcio passa por uma prova em que é degradado, para, somente posteriormente renascer com algo favorável: as honras e o favor do deus do Riso. No livro XI, Apuleio apóia-se na mesma perspectiva: após todos os infortúnios sofridos pelo Lúcio-Asno, retorna a sua antiga forma: a de homem. 
O sofrimento na narrativa foi o caminho iniciático de Lúcio: é necessário tornar-se um "espantalho cômico" (Bakhtin, 1999), para finalmente se regenerar e conquistar os favores da deusa Ísis, qual seja: entrar para o colégio dos pastóforos e elevar-se à ordem dos decuriões qüinqüenais. Além da ridicularização de Lúcio, que evidencia o grotesco, a narrativa apresenta a festa do deus por uma carnavalização social, pelo descarrego de tensões reprimidas e pelo êxtase ${ }^{2}$. Assim como a carnavalização dionisíaca provoca a confusão universal, a abolição da ordem e das hierarquias, instalando a orgia, o caos e novas experimentações, a festividade do Riso, apresenta uma intencionalidade em ridicularizar os grupos sociais, as autoridades e o caráter oficial da sociedade romana provincial. Como propõe Minois (2003, p.36),

a loucura, doce para seus fiéis, terrível para seus inimigos. Esse intermédio de burlesco primário vem lembrar que o riso da loucura é necessário para o equilíbrio da cidade; porque ele se opõe ao logos racional representado por Apolo ou Atenas: Deus da loucura, da embriaguez, da ilusão, das forças misteriosas e selvagens da natureza como um Outro Mundo, de riquezas gratuitas que é preciso saber colher, saborear e alegremente festejar, Dioniso é necessário ao equilíbrio da cidade.

A contravenção, o deboche, a ridicularização de um notável, representado por Lúcio, atuam como inversões sociais, para ao final do ato festivo, manter-se a ordem social, pois, como na festa grega antiga, o riso ritualizado exorciza a desordem, os desvios e a bestialidade original (MINOIS, 2003, p.33). Esses desvios coletivos promovem, parafraseando Machado (2006, p.214), em relação a Dioniso, mas também em relação ao Riso, "a desintegração do eu, uma abolição da subjetividade até o total esquecimento de si: um desprendimento de si próprio, a dissolução do eu no mundo, um abandono ao êxtase divino, à loucura mística do deus da possessão". Uma renúncia de si com o objetivo de alcançar não apenas o êxtase divino, mas também, por meio destas comemorações, instaura-se a possibilidade de se colocar em um ato coletivo, em um ato social, não mais como indivíduos, mas como cidadãos que se unificam em torno de um objetivo comum: a crença no poder desses deuses.

A meu ver, podemos, a partir da comemoração ísiaca e a dos mascarados, as quais ocorrem na cidade de Concréias, interpretá-las como pontos de equilíbrios. Assim como proposto por Minois, comparando Dioniso, Apolo ou Atenas, pode-se pensar o culto isíaco como forma de celebrar o logos racional, enquanto o cortejo dos mascarados e o festejo do deus do Riso celebram a desordem que surge

sob a forma do riso e, ao mesmo tempo, é morta pelo riso, pela autoderrisão e pelas zombarias mútuas de todos esses atores mascarados que encarnam, cada um, um aspecto das proibições e medos. De um só 
O risível, o lastimoso e o ridente em Metamorfoses de Apuleio

golpe, a ordem social é recriada e confortada em sua normalidade. (MINOIS, 2003, p.33)

Esse riso ritualístico é imprescindível na narrativa apuleiana, podendo ser percebido no conto de Telifrão. Este narra ao protagonista Lúcio, em um banquete na casa de Birrena, suas desventuras ocorridas em um funeral público. Esse, precisando de dinheiro submete-se ao serviço de uma vigília fúnebre, para impedir o assalto tempestivo de feiticeiras, as quais roubam as partes do morto com os dentes, para realizar, com este material, suas artes mágicas (Apul. Met. 2.21-30). No dia seguinte, no ritual público do enterro, o tio do morto denuncia o assassinato de seu ente querido pela adúltera e o próprio cadáver, por interferência mágica, não só confirma o assassinato, mas conta acerca da mutilação do corpo do guardião feito pelas feiticeiras: metamorfoseadas em doninhas, chamando pelo nome do morto, atraem Telifrão, e retiram de seu corpo orelhas e nariz, reconstituindo-os com cera.

Ora, o que é interessante dessa ridicularização é a localidade: ocorre em um funeral público, pois, trata-se de um homem notável, por isso, o cortejo, passa pelo fórum. Nessa procissão, temos o envolvimento da multitudo, aclamando por justiça, solicita a condenação da adúltera e da assassina; esta por sua vez, nega às denúncias e o acusador principal, o tio do cádaver, com interesses próprios, os quais não foram explicitados no enredo, mas podem se associar à herança, a legitimidade de sua família no campo político, a qual estava sendo humilhada publicamente com o adultério entre outras motivações, conduziu a execração pública da adúltera. Ao mesmo tempo em que se apresentam as lamentações do tio, a revolta da multidão, surge na procissão, após a descoberta da amputação das partes do corpo de Telifrão, a pilhéria e o burlesco (Apul. Met. 2.30).

Essas situações aparecem de forma cadenciadas com o desfecho final, qual seja: o riso desenfreado da multitudo. Embora Minois (2003, p.96) interprete este conto somente pelo viés do grotesco, provocado pela mutilação das partes do corpo de Telifrão, em minha suposição, trata-se de um riso ritualístico, pois, tratase de mais uma comemoração ao deus do Riso, para assegurar aos cidadãos de Hípata, a cura, o renascimento, o ordenamento social e as permanências das estruturas de poder e, ao mesmo tempo, garante a mobilização e a participação da multitudo no espetáculo.

Pode-se, portanto, visualizar essa característica risível em todos os contos, ainda que exista também o grotesco, a pilhéria em situações do cotidiano, as quais foram anteriormente discutidas como no comportamento de avareza de Milão, o festejo dos mascarados e o do deus do Riso apresentam-se por risos ritualísticos, os quais são representados por divertimentos e encenações realizadas pelo povo, retratando os diversos grupos sociais por brincadeiras jocosas (Apul. Met. 11.7). O riso apuleiano tem um caráter, sobretudo, 
regenerador: depois do sofrimento, os personagens conquistam os favores dos deuses. Lúcio entra para o colégio dos pastóforos da deusa e é elevado a ordem dos decuriões, ao passo que Telifrão se salva da malfadada experiência com as feiticeiras, passando a ver a magia com respeito, alerta os convivas sobre os perigos dessas magas. Este caráter regenerador e iniciático dos personagens é acompanhado igualmente por um elemento imprescindível do festejo: o caráter unificador, pois, trata-se da mobilização de cidadãos de Hípata e de Concréias, envoltos na crença e na ritualidade, que os motiva para a realização das festas, sendo, por conseguinte, polos de agregações entre os devotos como símbolo de uma identidade.

\section{Fontes:}

APULEIO, L. Oeuvres complètes d'Apulée. Trad. Henri Clouard. Paris: Librairie Garnier Frères,19-?

APULEIO, L. O asno de Ouro. Tradução de Francisco Antônio de Campos. Portugal: EuropaAmérica, 1990.

\section{Bibliografia:}

BAKHTIN, M. A cultura popular na Idade Média e no Renascimento. Brasília: Universidade de Brasília, 1999.

BAKHTIN, M. Questões de literatura e de estética. A teoria do romance. Tradução de Bernadini, A. F.; Júnior, J. P.; Nazário, H. S.; Andrade, H. F. São Paulo: UNESP, 1998.

BALANDIER, G. O poder em cena. Brasília: UNB, 1982.

CONFINO, A. Collective Memory and Cultural History: problems of method. The American Historical Review, vol. 102, no 5, December, p.1386-1403, 1997.

FORTUNA, M. Dioniso e a comunicação na Hélade: o mito, o rito e a ribalta. São Paulo: Annablume, 2005.

GUARINELLO, N.L. Festa, trabalho e cotidiano. In: István Jancsó; Íris, Kantor. Festa, Cultura e sociabilidade na América portuguesa. São Paulo: Edusp, 2001, p.969-975.

GUARINELLO, N.L. Império Romano e Identidade Grega. In: FUNARI, P. P. A.; SILVA, Maria A. de. Política e identidades no mundo antigo. São Paulo: Annablume, FAPESP, 2009.

GONÇALVES, A.T.M. As comemorações severianas: festejando e construindo memórias. In: LESSA, F.S.; BUSTAMANTE, R.M.C. (org.). Memória e Festa. Rio de Janeiro: Mauad, 2005.

GONÇALVES, Ana Teresa Marques; ROCHA, Leandro Mendes. Identidades e Etnicidades: conceitos e preceitos. In: Silva, Gilvan Ventura da; NADER, Maria Beatriz e FRANCO, Sebastião Pimentel (orgs). As identidades no tempo. Ensaios de gênero, etnia e religião. Vitória: EDUFES, 2006.

MACHADO, R. Nietzsche e a representação do dionisíaco. In: O nascimento do trágico: de Schiller a Nietzsche. Rio de Janeiro: Jorge Zahar, 2006, p.202-246.

MINOIS, G. História do riso e do escárnio. São Paulo: UNESP, 2003.

MOTTA, S.V. O engenho da narrativa e sua árvore genealógica. Das origens a Graciliano Ramos e Guimarães Rosa. São Paulo: UNESP, 2006.

OGDEN, D.; LUCK, G.; GORDON, R.; FLINT, V. Bruxaria e magia na Europa: Grécia antiga e Roma. São Paulo: Madras, 2004. 


\section{O risível, o lastimoso e o ridente em Metamorfoses de Apuleio}

PEREZ, L.F. Antropologia das efervescências coletivas. In: PASSOS, Mauro. A Festa na vida. Significado e imagens. Rio de Janeiro: Vozes, 2002, p.15-58.

ROSA, G. Grande sertão: veredas. Rio de Janeiro: Nova Fronteira, 2006.

SCARPI, P. Egito, Roma, Grécia, mesopotâmia, Pérsia. Politeísmos: as religiões do mundo antigo. São Paulo: HEDRA, 2004.

TRABULSI, A.D. Doinisismo, poder e sociedade na Grécia até o fim da época clássica. Belo Horizonte : UFMG, 2004.

\section{Notas}

${ }^{1}$ Ainda segundo Fortuna (2005, p.79), Osíris também ensinou ao povo o cultivo dos grãos. Diferentemente da vinha, foram o trigo e a cevada, que cresciam selvagens, descobertos por sua esposa Ísis. Diz a lenda ter sido Osíris o primeiro a colher os frutos das árvores, atar as parreiras e pisar a uva para o vinho. Assim como Dioniso, Osíris desejou comunicar as descobertas a toda a humanidade e pelo mundo vagou durante muito tempo, incentivando o desenvolvimento da agricultura (vinha e cerveja de cevada) por onde passasse".

${ }^{2} \mathrm{O}$ riso e a visão carnavalesca do mundo, que estão na base do grotesco, destroem a seriedade unilateral e as pretensões de significado incondicional e intemporal e liberam a consciência, o pensamento e a imaginação humana, que ficam assim disponíveis para o desenvolvimento de novas possibilidades (BAKHTIN, 1999, p.43). 